\title{
MANAJEMEN KINERJA KELEMBAGAAN DALAM \\ MENINGKATKAN KUALITAS AIR BERSIH PADA PERUSAHAAN \\ DAERAH AIR MINUM
}

\author{
${ }^{1}$ Andri Pratama Saputra, ${ }^{2}$ Mohamad Ichsana Nur \\ ${ }^{1}$ Fakultas Ilmu Administrasi, Universitas Indonesia; saputraandrepratama@yahoo.com \\ ${ }^{2}$ Fakultas Ilmu Sosial dan Ilmu Politik, UIN Sunan Gunung Djati Bandung; mohamadichsana22@uinsgd.ac.id
}

\begin{abstract}
Performance mangement issues in local water company, which is called PDAM, in Indonesia are often encountered such as slow service in serving public needs and complaints. In 2013, the performance of PDAMS was categorized as unhealthy with a total performance value of 2.50 (ranging from 2.2 to 2.8). This research aims to analyze performance evaluations of Badan Pendukung Pengembangan Sistem Penyediaan Air Minum as a performance appraisal body of PDAM and what kind of factors influencing the performance through the PDAM performance assessment techinical guidelines. The approach used in this paper is quantitative with descriptive research. The data collection of this research is literature study. The results show that the greater the NRW level and the employee ratio, the worse the PDAM performance. For other indicators identified as having positive causality because the greater the value, the better the performance value.
\end{abstract}

Keywords: Public Service, Performance Management, Performance Appraisal System, Corporate Governance 


\section{Pendahuluan}

Air adalah termasuk kebutuhan dasar masyarakat dalam menjalani kehidupan. Menurut UU No 25 Tahun 2009, pariwisata yang merupakan ruang lingkup pelayanan publik. Menurut data Foogden dan Wood (2009), bahwa kebutuhan masyarakat dunia terhadap air berkisar 20 liter per hari, yang mana 4 liter untuk konsumsi dan sisanya untuk kebutuhan lainnya seperti memasak dan sebagainya. Ketersediaan air minum merupakan masalah yang dihadapi hampir di seluruh dunia. Menurut data UNICEF (2012) kualitas air yang rendah akan menurunkan probabilitas meninggalnya balita sebesar 1,3 juta per tahun. Dalam kaitannya dengan sumber pangan, air minum menjadi hal utama yang harus diperhatikan dan menjadi permasalahan termasuk di Indonesia. Menurut data Badan Pusat Statistik (2015), rata-rata air bersih di setiap kabupaten hanya tercapai $49 \%$ dan sisanya tak layak konsumsi. Permasalahan lainnya ialah permintaan air minum yang terus meningkat dihadapkan dengan ketersediaan air layak konsumsi yang kurang.. Kurangnya air layak konsumsi ini akan mempengaruhi Indeks Pembangunan Manusia (IPM) karena berhubungan dengan pemenuhan kebutuhan hidup masyarakat di suatu negara.

Dalam menyediakan air bersih terdapat sejumlah perusahaan yang berfokus pada penyediaan air bersih. Berikut data jumlah perusahaan penyedia layanan air bersih.

Tabel 1.1

Jumlah Perusahaan Air Bersih di Indonesia

\begin{tabular}{|c|c|}
\hline Tahun & Jumlah \\
\hline 2011 & 542 \\
\hline 2012 & 547 \\
\hline 2013 & 537 \\
\hline 2014 & 539 \\
\hline 2015 & 539 \\
\hline
\end{tabular}

Sumber: Dokumen BPS tahun 2015 dalam bps.go.id 
Data di atas menunjukkan bahwa masih banyaknya perusahaan air bersih di Indonesia, namun sejumlah perusahaan tersebut kurang sebanding dengan kapasitas produksi air bersih di Indonesia. Berikut data mengenai kapasitas produksi air bersih di Indonesia yang diukur melalui kapasitas efektif yang dihadapkan dengan kapasitas potensial yang ada.

Tabel 1.2

Kapasitas Produksi Air Bersih

\begin{tabular}{|c|c|c|}
\hline \multirow{2}{*}{ Tahun } & \multicolumn{2}{|c|}{ Jumlah Kapasitas (liter/detik) } \\
\cline { 2 - 3 } & Kapasitas Potensial & 149,960 \\
\hline 2011 & 187,065 & 149,543 \\
\hline 2012 & 182,588 & 148,781 \\
\hline 2013 & 182,267 & 146,565 \\
\hline 2014 & 183,508 & 167,915 \\
\hline & & 209,320 \\
\hline
\end{tabular}

Dari data di atas dapat diketahui bahwa ketersediaan air munim bersih oleh perusahaan penyedia masih kecil jika dibandingkan dengan potensi yang ada. Hal tersebut didukung oleh data yang dikeluarkan Badan Pusat Statistik (2015), rata-rata air bersih di setiap kabupaten hanya tercapai $49 \%$ dan sisanya tak layak konsumsi. Hal ini menjadi pekerjaan rumah dari perusahaan air bersih di Indonesia termasuk salah satunya adalah Perusahaan Daerah Air Minum (PDAM).

PDAM yang merupakan BUMN memiliki tugas untuk menyalurkan air minum yang merupakan salah satu kebutuhan utama masyarakat, selain mengejar profit, PDAM juga memiliki tugas dalam melayani kebutuhan masyarakat akan air bersih. Oleh sebab itu, PDAM dituntut untuk mengelola dan memadukan prinsip ekonomi dan sosial. Namun, dalam 
kenyataannya, sumber daya yang dimiliki PDAM masih belum maksimal dalam meningkatkan kinerja sehingga merurunkan kepercayaan masyarakat dan mengurangi profit itu sendiri. Keluhan-keluhan yang dialami seperti pipa bocor, air mati mendadak, meteran air yang tidak sesuai, serta penyelesaian keluhan masyarakat yang tidak selesai semakin menurunkan kinerja PDAM.

Badan Pendukung Pengembangan Sistem Penyediaan Air Minum (BPSPAM) sebagai badan penilai kinerja dari PDAM, menilai kinerja dan faktor apa yang mempengaruhi kinerja tersebut seperti pada aspek sumber daya manusia, keuangan, operasional, dan pelayanan. Keempat aspek ini dinilai sangat tepat dalam mengukur bagaimana manajemen kinerja di PDAM. Prinsip penilaian yang dugunakan BPSPAM adalah dengan menggunakan balance score card. Pada tahun 2013 kinerja PDAM dikategorikan kurang sehat dengan total nilai kinerja sebesar 2,50 (berkisar 2,2-2,8) Kategori tersebut didapatkan dari perincian: (1) Indikator sehat, yaitu >2,8, (2) Indikator kurang sehat, yaitu 2,2-2,8, (3) Indikator sakit, yaitu $<2,2$. Berikut rinciannya:

Tabel 1.3

Penilaian Kinerja PDAM oleh BPSPAM tahun 2015

\begin{tabular}{|c|c|}
\hline Aspek & Penilaian \\
\hline Keuangan & 0,47 \\
\hline Pelayanan & 0,65 \\
\hline Operasional & 1,15 \\
\hline Sumber Daya Manusia & 0,23 \\
\hline \\
Sumber : Dokumen BPSPAM Tentang Petunjuk Teknis Penilaian Kinerja Tahun 2015
\end{tabular}


Berdasarkan data di atas tersebut,dapat dilihat bahwa seluruh aspek penilaian kinerja PDAM oleh BPSPAM masih rendah. Hal ini menjadi pekerjaan rumah PDAM dalam meningkatkan kinerjanya. Peningkatan kinerja di PDAM tak terlepas dari manajemen kinerja di sebuah organisasi.

Manajemen kinerja adalah usaha dalam meningkatkan kinerja anggota yang berimplikasi terhadap peningkatan kinerja di sebuah organisasi. Wibowo (2013) berpendapat bahwa manajemen kinerja mula-mula ditulis oleh pakar manajemen Peter Draker yang digunakan untuk menkingkatkan kinerja perusahaan multinasional, setelah itu ide tersebut dikembangkan hingga sekarang baik di organisasi publik maupun swasta. Rucky (2004) menyebutkan bahwa manajemen kinerja berkaitan dengan kegiatan, program, atau usaha yang diinisiai dan dijalankan oleh pimpinan organisasi untuk merencanakan, mengarahkan, dan mengawasi prestasi karyawan. Manajemen kinerja merupakan isu yang krusial harus diperhatikan oleh setiap anggota organisasi dalam meningkatkan kinerja. Indikator manajemen kinerja pun beragam yang dilihat dari apa saja faktor dalam meningkatkan kinerja tersebut (Umam, 2014).

Yacub (2010) berpendapat bahwa kinerja organisasi dipengaruhi oleh kepemimpinan, motivasi, dan lingkungan organisasi. Selanjutnya Wibowo (2013) berpendapat bahwa kinerja organisasi tak terlepas dari struktur organisasi, pengetahuan, sumber daya manusia, dan posisi strategis. Mangkunegara (2009) melihat bahwa kinerja organisasi merupakan tolak ukur keberhasilan organisasi yang tak terlepas dari hasil capaian kinerja anggota organisasi secara kolektif dalam melaksanakan tugasnya sesuai dengan tanggung jawab yang diberikan kepadanya. Selanjutnya, Wibowo (2013) berpendapat bahwa kinerja organisasi tak terlepas dari struktur organisasi, pengetahuan, sumber daya manusia, dan posisi strategis. Lebih lanjut, Ghergina, Paduva, dan Postole (2009) mengatakan konsep kinerja adalah sebuah usaha untuk 
melakukan sesuatu menjadi mungkin dan juga merupakan hasil dari aksi dan proses yang dicapai melalui waktu. Pentingnya kinerja organisasi dijabarkan lanjut oleh Ghergina, Paduva, dan Postole (2009) yang menjelaskan kinerja merepresentasikan kompetisi institusi dalam meraih level efektivfitas dan efisiensi di dalam kompetisi pasar Indikator kinerja diterapkan untuk mengembangkan manajemen kinerja. Pengembangan manajemen kinerja dilakukan sesuai dengan organisasi masing-masing termasuk organisasi publik termasuk di PDAM.

BPSPAM sebagai badan penilai kinerja dari PDAM melakukan penilaian kinerja dan faktor apa yang memperngaruhi kinerja tersebut melalui Petunjuk Teknik Penilaian Kinerja PDAM yang meliputi aspek keuangan, pelayanan, operasional, dan sumber daya manusia. Prinsip penilaian yang digunakan BPSPAM adalah dengan menggunakan balance score card. Pentingnya penilaian kinerja dalam penyediaan air juga didukung oleh Livingston (2008) yang berpendapat evaluasi penyediaan air berfungsi untuk menilai lingkungan khususnya dalam nilai pasar secara langsung sebagai panduan dalam penyediaan air yang bersih dan sebagai panduan dalam produksi air.

Minimnya air bersih di Indonesia menjadi masalah yang harus diperhatikan. Banyaknya perusahaan air di Indonesia belum sebanding dengan jumlah efektivitas ketersediaan air bersih. Hal itu menjadi perhatian setiap perusahaan termasuk PDAM. Perusahaan Daerah Air Mineral yang merupakan BUMN dituntut untuk meningkatkan kinerjanya yang tak hanya meningkatkan profit, tetapi juga meningkatkan aspek sosial yaitu meningkatkan jumlah air bersih. Permasalahan yang dihadapi seperti seperti lambannya pelayanan dalam melayani keluhan masyarakat, kualitas air bersih yang minim, serta pipa yang bocor menjadi perhatian yang harus diselesaikan. BPSPAM sebagai penilai eksternal PDAM melakukan penilaian bagaimana kinerja di PDAM dengan menggunakan balance 
score card yang terdiri dari aspek keuangan, pelayanan, operasional, dan sumber daya manusia. Dari latar belakang tersebut, maka penelitian ini bertujuan untuk:

1. Menganalisis bagaimana manajemen kinerja di PDAM yang dilihat dari aspek keuangan, pelayanan, operasional, dan sumber daya manusia.

2. Menganalisis apa saja yang paling berpengaruh terhadap kinerja PDAM sehingga dinilai Kurang Sehat dan Sakit.

\section{Metode Penelitian}

Penelitian ini menggunakan pendekatan kuantitatif dengan tipe penelitian deskriptif. Penelitian ini meneliti bagaimana manajemen kinerja di PDAM yang dilihat dari berbagai aspek seperti sumber daya manusia, keuangan, pelayanan, operasional, serta faktor apa saja yang mempengaruhinya yang merupakan salah satu indikator dari teori Bain \& Company (2009). Lokus penelitian ini adalah di PDAM pusat. Dalam melakukan pengumpulan data, penelitian ini juga menggunakan studi pustaka data sekunder seperti dokumen dan penelitian terdahulu. Dalam melakukan analisis data, penelitian ini melakukan beberapa tahap seperti reduksi data, penyajian data, triangulasi, serta penarikan kesimpulan. 


\section{Hasil dan Pembahasan}

Tabel di bawah ini merupakan ringkasan evaluasi kinerja PDAM di Indonesia tahun 2015:

Tabel 3.1

Ringkasan Kinerja PDAM Tahun 2015

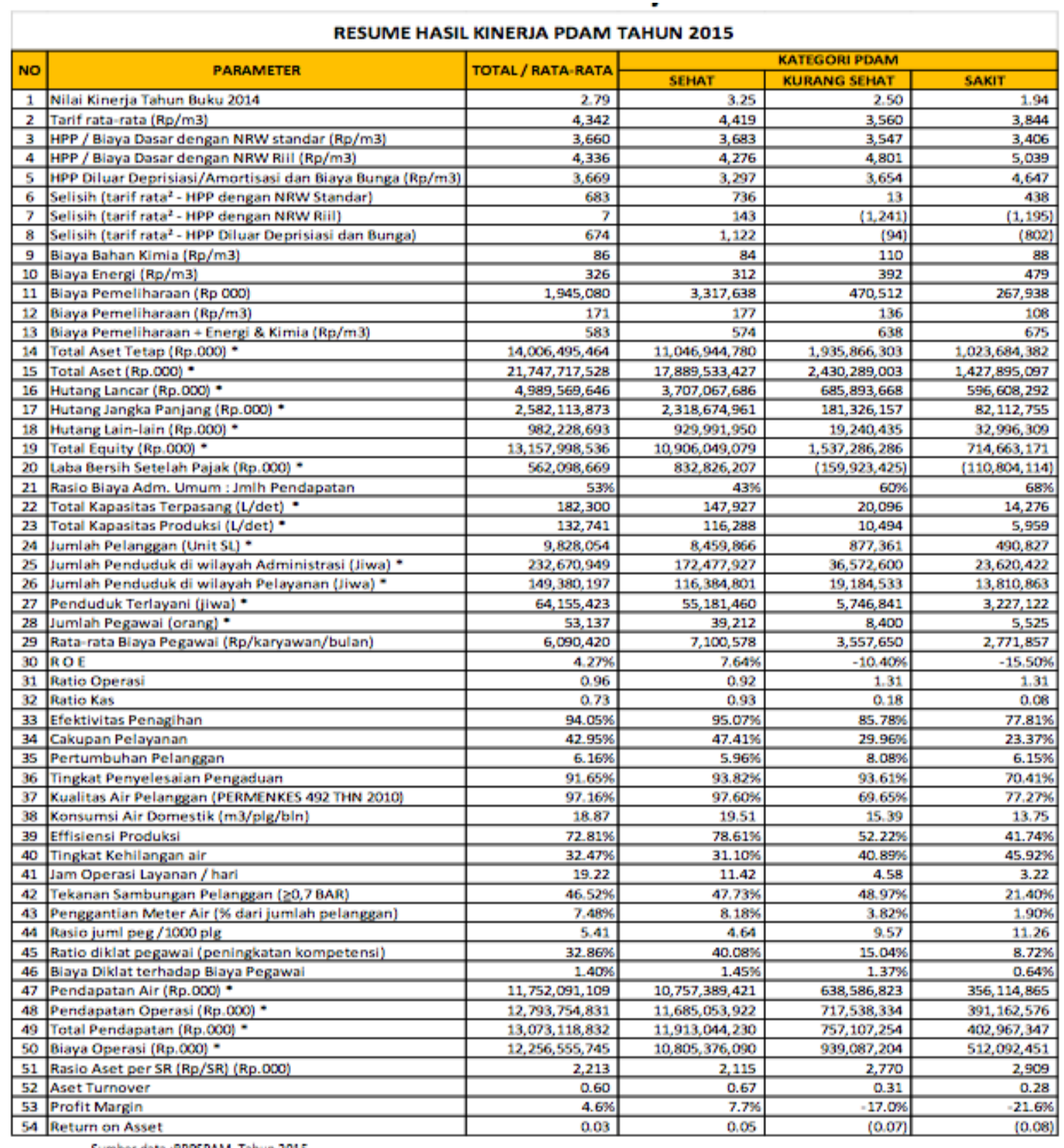

Sumber data :BPPSPAM, Tahun 2015 
Berdasarkan tabel di atas, secara jelas dapat dilihat bahwa dalam rangka menilai sejumlah indikator kinerja bernilai rendah dan untuk bisa memahami faktor penyebabnya, maka digunakan langkah analisis konsolidasi dan analisis parsial. Analisis konsolidasi ini adalah analisis kualitatif yang bertujuan untuk memahami hubungan antara satu indikator kinerja dengan indikator kinerja lainnya, dengan menggunakan metode causal loop diagram, yaitu suatu visualisasi hubungan sebab akibat antara beberapa variabel.

Beberapa variabel di dalam diagram kemudian dihubungkan dengan anak panah. Anak panah juga menandai mana yang menjadi variabel aksi (yang mempengaruhi) dan variabel reaksi (yang terpengaruh). Ada dua tipe korelasi yang terjadi, yaitu: korelasi positif mengindikasikan adanya pengaruh linier atau berbanding lurus antarvariabel dan korelasi negatif yang mengindikasikan terjadinya pengaruh berkebalikan antarvariabel.

Gambar 3.2.

\section{Diagram Causal Loop}

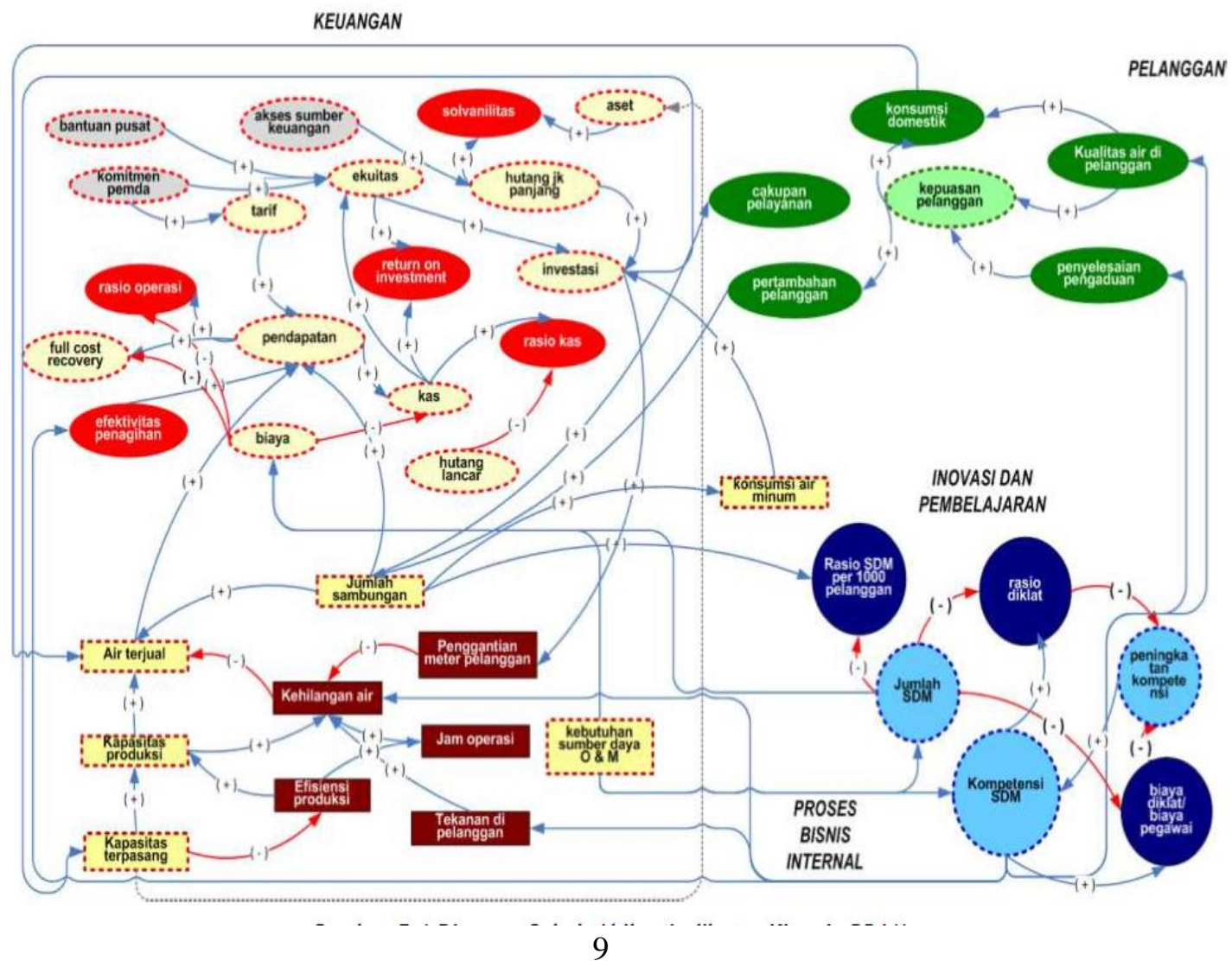


Dari gambar 3.1 diatas, telah dipetakan berbagai kemungkinan korelasi antar variabel dalam operasional PDAM. Akan tetapi dalam laporan kinerja yang dibuat oleh BPPSPAM hanya dibahas secara rinci untuk cakupan nasional sebanyak lima variabel yang kemudian dianggap sebagai indikator yang paling berpengaruh dalam menilai kinerja PDAM, yaitu 1) biaya tarif Full Cost Recovery (FCR); 2) tingkat Non Revenue Water (NRW); 3) Jumlah Pelanggan; 4) Efektifitas Penagihan; 5) Rasio Pegawai Per Pelanggan.

1. Maksud dari tarif Full Cost Recovery (FCR) adalah pengembalian biaya secara penuh, yaitu tarif rata-rata PDAM harus bisa mencapai biaya minimal atau dasar sama dengan biaya dasar PDAM. Penerapan tarif FCR cukup penting dalam memenuhi biaya perawatan, pengembangan, dan operasional lainnya.

2. Tingkat Non Revenue Water (NRW) adalah air tak berekening atau kehilangan air, entah karena terjadi kebocoran atau bisa jadi akibat pemakaian air secara illegal. Tingkat NRW ini tidak hanya merugikan secara finansial namun juga bisa merugikan pelanggan seperti berkurangnya volume suplai air yang mengalir ke mereka.

3. Jumlah pelanggan juga menjadi indikator penting yang berpengaruh terhadap kinerja PDAM karena fakta di lapangan memperlihatkan bahwa sebagian PDAM belum mampu menanggung biaya gaji pegawai karena jumlah pelanggan juga terbatas.

4. Efektifitas penagihan menjadi tolok ukur kinerja PDAM, karena semakin tinggi ketercapaian penagihan suatu PDAM, maka artinya mereka mampu mengelola pendapatan dari hasil penjualan air sehingga menjadi penerimaan kas.

5. Rasio pegawai per pelanggan menjadi indikator berpengaruh dalam menilai kinerja PDAM karena dapat menunjukkan seberapa besar nilai efisiensi dari jumlah tenaga kerja dalam melayani setiap 1000 pelanggan. Kondisi yang banyak terjadi sampai saat 
ini adalah PDAM belum mampu mengelola efisiensi pegawai sehingga beban finansial pun menjadi berat.

Mengacu pada pemetaan diagram causal loop, pemilihan kelima indikator ini dipahami sebagai variabel yang memiliki pengaruh atau dipengaruhi oleh pendapatan dan pengeluaran (biaya).

1. Full Cost Recovery (FCR) merupakan variabel reaksi dari variabel pendapatan dan biaya. Variabel pendapatan memiliki korelasi positif terhadap FCR, artinya semakin besar pendapatan PDAM maka semakin besar peluang mencapai FCR. Sedangkan variabel biaya memiliki korelasi negative terhadap FCR karena semakin besar biaya yang dikeluarkan maka semakin kecil peluang untuk mencapai FCR. Dikaitkan dengan variabel tariff, korelasinya adalah positif, artinya semakin tinggi tariff yang diberlakukan maka peluang mencapai FCR juga semakin besar.

2. Tingkat Non Revenue Water (NRW) merupakan variabel aksi terhadap variabel air terjual. Variabel NRW memiliki korelasi negative terhadap air terjual, artinya semakin besar NRW atau kehilangan air, maka semakin kecil air yang terjual. Mengingat variabel air terjual berkorelasi positif terhadap pendapatan, maka NRW turut memiliki pengaruh terhadap besar kecilnya pendapatan.

3. Jumlah pelanggan (jumlah sambungan) merupakan variabel aksi terhadap variabel pendapatan. Variabel jumlah pelanggan memiliki korelasi positif terhadap pendapatan, artinya semakin banyak jumlah sambungan (pelanggan) maka akan semakin besar pendapatan yang akan diperoleh PDAM.

4. Efektifitas penagihan merupakan variabel aksi terhadap variabel pendapatan. Efektifitas penagihan berkorelasi positif kepada pendapatan, artinya semakin efektif penagihan dilakukan, maka pendapatan kas PDAM juga akan bertambah. 
5. Rasio pegawai per pelanggan merupakan variabel reaksi (korelasi positif) dari variabel jumlah SDM, sedangkan variabel jumlah SDM merupakan variabel aksi (korelasi positif) untuk variabel biaya. Hal ini berarti setiap penambahan pegawai menghasilkan peningkatan terhadap rasio SDM per pelanggan dan memperbesar biaya yang harus dikeluarkan oleh PDAM.

Gambar 3.3 sampai dengan Gambar 3.4 memuat ilustrasi mengenai keterkaitan masing-masing indikator yang berpengaruh terhadap kinerja PDAM.

Gambar 3.3.

Jumlah PDAM berdasarkan tarif FCR

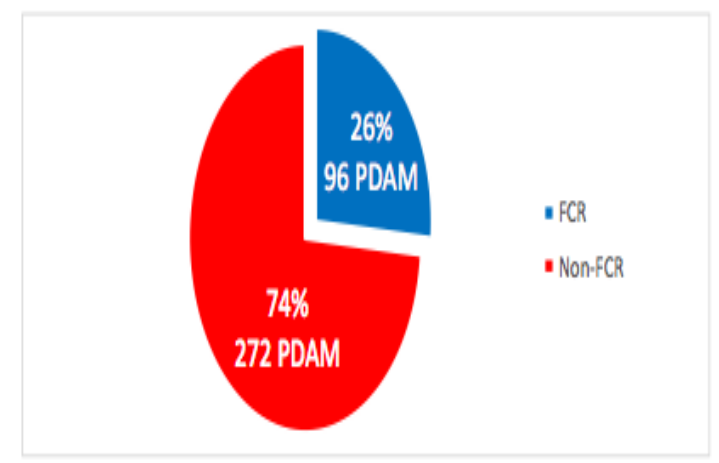

Sumber data : BPPSPAM, Tahun 2015
Gambar 3.4.

Tarif FCR dikaitkan dengan Kinerja PDAM

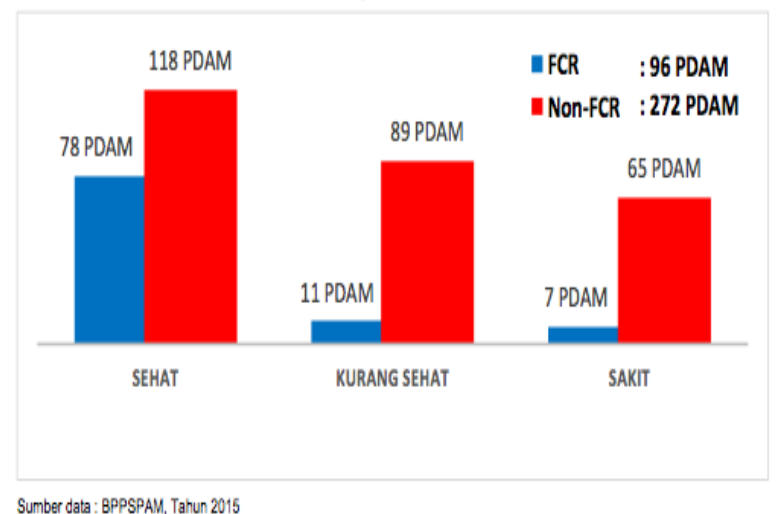

Dari gambar 4 dan 5, dapat ditarik kesimpulan bahwa masih terdapat 272 atau sebesar 74\% PDAM yang belum menerapkan tarif FCR. Bahkan, ketika dikaitkan dengan klasifikasi kinerja PDAM, yang dikategorikan sebagai "PDAM Sehat" pun, jumlah yang belum menerapkan tariff FCR masih lebih besar dibandingkan yang sudah. 
Gambar 3.5.

Jumlah PDAM Berdasarkan Tingkat NRW

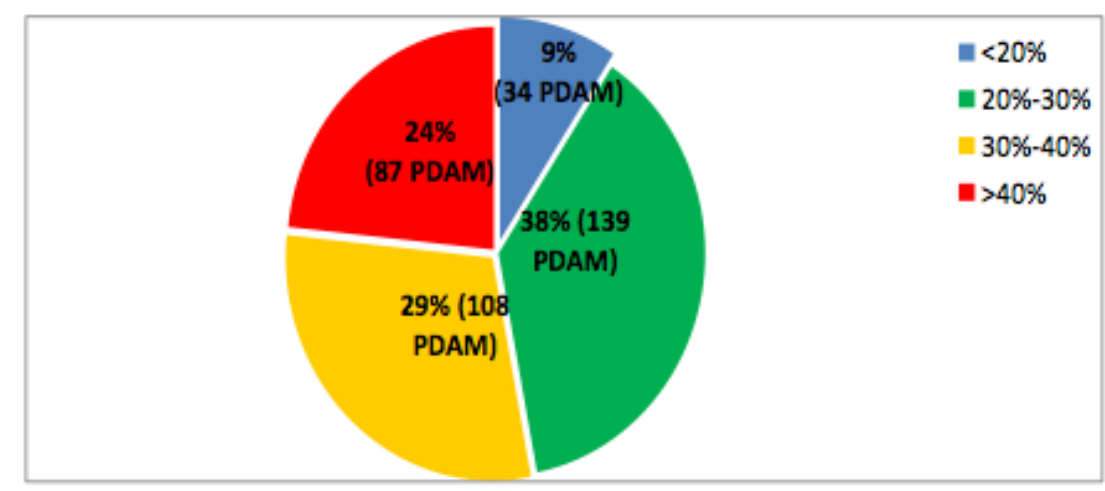

Gambar 3.6.

Tingkat NRW dikaitkan dengan Kinerja PDAM

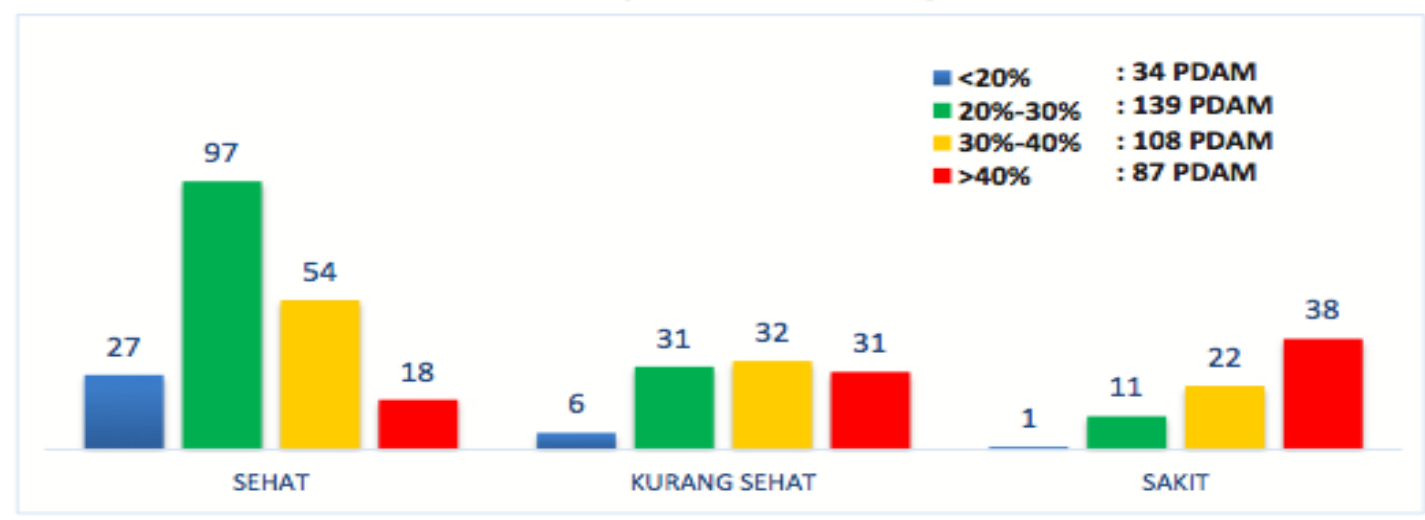

Dari gambar 3.5 dan 3.6, bisa diketahui bahwa PDAM yang mengalami tingkat kebocoran lebih dari 30\% sebanyak 195 institusi (53\%). Hal lain yang juga dapat dicermati dari gambar 6 adalah kecenderungan bahwa sebagian besar PDAM di Indonesia memiliki tingkat NRW antara 20\%-40\%. Ketika dikaitkan dengan kategori kinerja PDAM, jumlah PDAM yang mengalami tingkat kebocoran di atas 30\% tersebar merata di kategori "Sehat", "Kurang Sehat", maupun "Sakit". Beberapa informasi lain yang bisa disimpulkan dari gambar 7 adalah :

- $\quad$ Tingginya tingkat NRW berpengaruh negatif terhadap tingkat kinerja PDAM.

- $\quad$ Tingkat NRW di atas 40\% paling besar adalah PDAM dengan kategori "Sakit". 
Gambar 3.7.

Jumlah PDAM Berdasar Jumlah SR

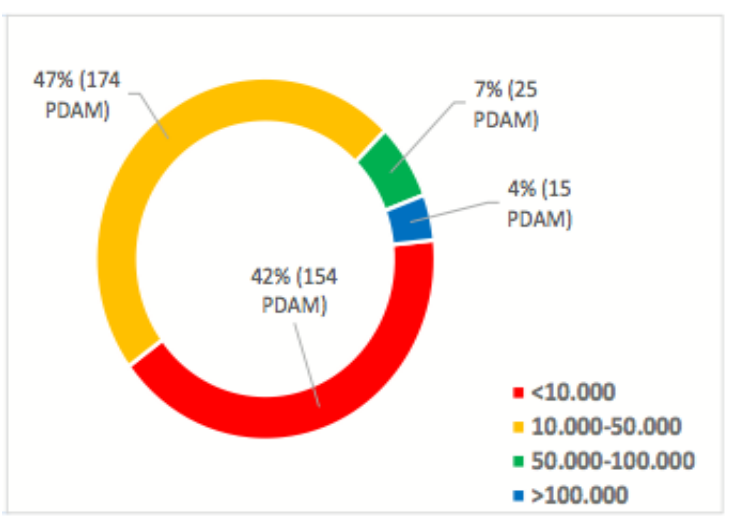

Gambar 3.8.

Jumlah SR dikaitkan dengan Kinerja PDAM

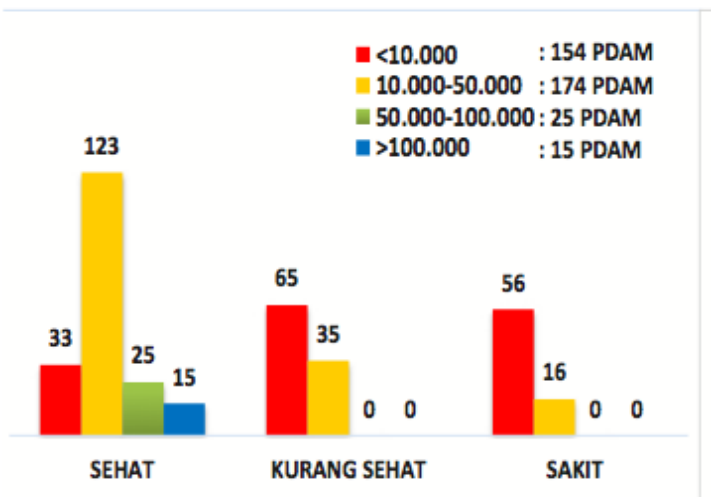

Gambar 3.7 dan 3.8 menginformasikan mengenai indikator jumlah pelanggan yang didasarkan pada SR (sambungan rumah). Gambar 8 menunjukkan bahwa PDAM yang memiliki pelanggan dengan jumlah signifikan (di atas 50.000 ) ternyata hanya sebesar $11 \%$. Sedangkan PDAM yang pelanggannya nerjumlah dibawah 10.000 mencapai 154 atau $42 \%$ dari total PDAM. Kemudian PDAM yang total pelanggannya antara 10.000-50.000 mencapai 174 atau 47\% dari total PDAM. Jika dikaitkan dengan kategori kinerja, terlihat bahwa jumlah pelanggan di atas 50.000 SR hanya dapat ditemui pada kategori PDAM Sehat. Sedangkan PDAM dengan kondisi yang kurang sehat, jumlah pelanggannya dibawah 50.000. Oleh karenanya, dapat ditarik kesimpulan bahwa terdapat keterkaitan langsung antara jumlah pelanggan dengan keberlangsungan kinerja PDAM. 
Gambar 3.9.

Jumlah PDAM Berdasar Efektifitas Penagihan
Gambar 3.10.

Kinerja PDAM
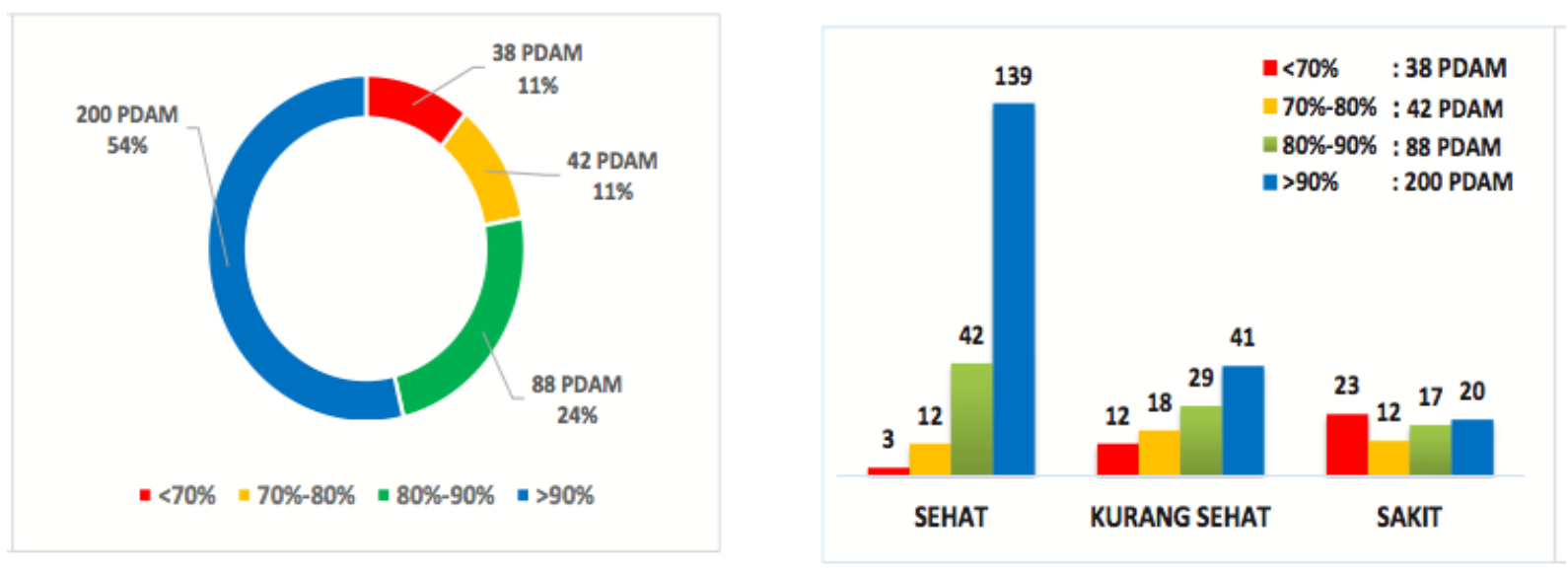

Gambar 3.9 dan 3.10 menginformasikan mengenai efektifitas penagihan. Terlihat bahwa sebanyak 288 PDAM memiliki tingkat efektifitas penagihan di atas $80 \%$. Apabila indikator ini dikaitkan dengan kinerja, maka terlihat bahwa PDAM yang memiliki tingkat efektifitas penagihan di atas $90 \%$ paling banyak, berada pada kategori "Sehat". Kesimpulannya adalah efektifitas penagihan turut mempengaruhi kondisi finansial dan kinerja PDAM.

Gambar 3.11.

Jumlah PDAM Berdasar

Rasio Pegawai Per Pelanggan

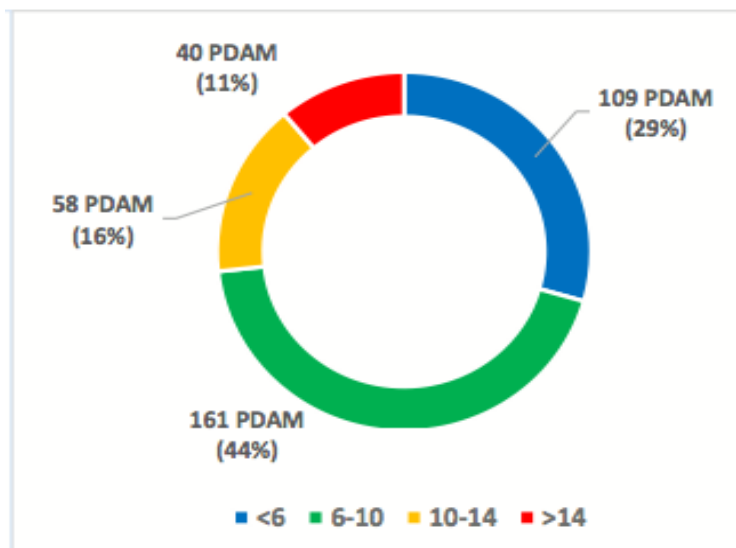

Gambar 3.12.

Rasio Pegawai Per Pelanggan

dikaitkan dengan Kinerja PDAM

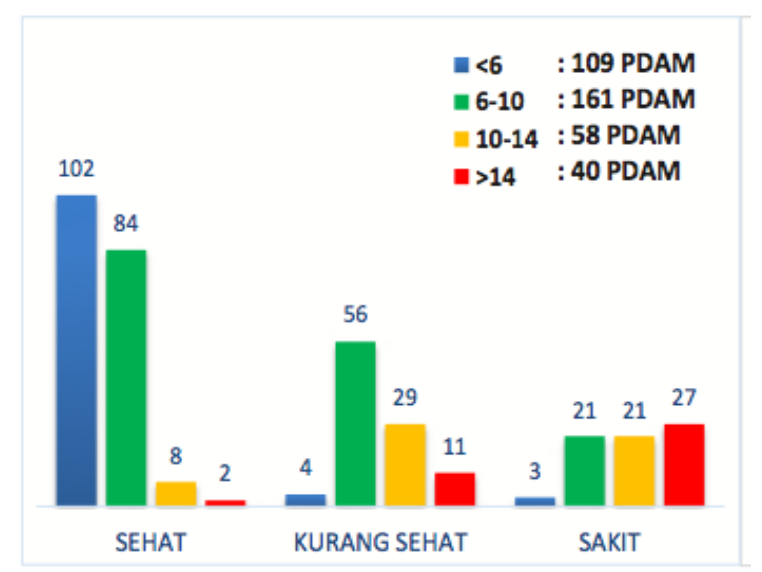


Dari gambar 11 dan 12, informasi yang kita dapat kita peroleh adalah bahwa PDAM yang Sehat adalah yang memiliki rasio pegawai per pelanggan di bawah angka 10 (1 pegawai untuk 100 pelanggan). Dengan demikian dapat disimpulkan bahwa efisiensi dalam penggunaan tenaga kerja menjadi salah satu indikator yang berpengaruh terhadap kinerja PDAM.

\section{Simpulan}

Berdasarkan telaah peneliti dari buku evaluasi kinerja PDAM tahun 2015 yang diterbitkan oleh BPPSPAM, terlihat bahwa kelima indikator di atas diidentifikasi sebagai indikator yang paling berpengaruh terhadap performa kinerja PDAM. Mengapa demikian? Karena peneliti mencermati bahwa lima indikator tersebut berkaitan langsung dengan besar kecilnya pendapatan dan pengeluaran PDAM. Empat indikator pertama memberikan kontribusi terhadap harga satuan per produk (FCR), jumlah penawaran produk (NRW), jumlah permintaan terhadap produk (Pelanggan/SR), dan kelancaran transaksi (Penagihan). Sedangkan indikator terakhir (Rasio Pegawai Per Pelanggan) berkaitan dengan anggaran belanja pegawai. Adapun untuk mengetahui jenis pengaruh masing-masing indikator terhadap kinerja, peneliti melihat bahwa yang memberikan kausalitas negatif adalah indikator NRW dan Rasio Pegawai Per Pelanggan. Semakin besar tingkat NRW dan Rasio Pegawai, maka semakin buruk kinerja PDAM. Untuk indikator lainnya diidentifikasi memiliki kausalitas positif sebab semakin besar nilainya maka semakin bagus nilai kinerjanya. 


\section{Referensi}

Artikel Key Elements of Effective Organizations: Bridgespan's Organization Wheel (http://executiveleadershipllc.blogspot.co.id/2011) diakses pada tanggal 14 Desember 2017 Pukul 21.45 WIB.

BPPSPAM. 2015. Laporan Kinerja PDAM Tahun 2015 Wilayah I Pulau Sumatra. Jakarta: BPPSPAM, Kementerian Pekerjaan Umum dan Perumahan Rakyat

BPPSPAM. 2015. Laporan Kinerja PDAM Tahun 2015 Wilayah II Pulau Jawa. Jakarta: BPPSPAM, Kementerian Pekerjaan Umum dan Perumahan Rakyat

PPSPAM. 2015. Laporan Kinerja PDAM Tahun 2015 Wilayah III Pulau Kalimantan, Pulau Sulawesi. Jakarta: BPPSPAM, Kementerian Pekerjaan Umum dan Perumahan Rakyat BPPSPAM. 2015. Laporan Kinerja PDAM Tahun 2015 Wilayah IV Papua, Maluku, NTT, NTB, Bali. Jakarta: BPPSPAM, Kementerian Pekerjaan Umum dan Perumahan Rakyat

David, F.R. (2010) Strategic Management $12^{\text {th }}$ Edition. Diterjemahkan oleh Dono SUnardi. Jakarta: Salemba Empat

Dokumen BPS tahun 2015 tentang jumlah perusahaan penyedia air bersih dan jumlah kapasitas air bersih di Indonesia (https://www.bps.go.id/index.php/publikasi/4362) ), diakses pada tanggal 14 Desember 2017 Pukul 21.55 WIB.

Ghergina, Rodica, Vaduva Florin, dan Mirela Anca Postole. (2009). The Performance in Public Institutions of Higher Education and The Economic Crisis. Annales Universtitatis Apaulensis Series Oeconomica. 11(2): 639-643 
Kementerian Pekerjaan Umum; BPPSPAM. 2016. Petunjuk Teknis Penilaian Kinerja PDAM. Jakarta: Kementerian Pekerjaan Umum; BPPSPAM.

Livingston, Marie Leigh. (2008). Evaluating Institutional Performance: An Ex Post Analysis of Water Law in Colombia. Acta Oenomica Progensia. 16(3):70-80.

Mangkunegara,A, P.(2009). Manajemen Sumber Daya Aparatur. Bandung: Refika Aditama.

Rucky, A. (2004). Sistem Manajemen Kinerja. Jakarta: PT Gramedia Pustaka.

Supriyanto, Agus., dkk. (2017). Mencipta Inovasi. Inovasi Untuk Pencapaian Tujuan Pembangunan berkelanjutan. Jakarta: PT. Temprint

Umam, K. (2014). Manajemen Perkantoran. Bandung: CV. Pustaka Setia

UNDP. (2011). Governance Principles Institutional Capacity and Quality. New York:UNDP.

Van Dooren, W., Bouckaert, G., and Haligan, J. (2015). Performance Management In The Public Sector. London \& New York: Rotledge.

Wibowo. 2013. Manajemen Kinerja. Jakarta: Rajawali Press.

Yacub, R., dan Rifel, M,M. (2010). Pengaruh Kepemimpinan Atasan dan Lingkungan Organisasi terhadap Kinerja Pegawai. Jurnal Ilmiah Penelitian Manajemen Manajerial 8 (2):1-16. 